\title{
Factors affecting gain of beef bulls consigned to a central test station
}

\author{
C. L. Franklin
}

Follow this and additional works at: https://researchrepository.wvu.edu/ wv_agricultural_and_forestry_experiment_station_bulletins

\section{Digital Commons Citation}

Franklin, C. L., "Factors affecting gain of beef bulls consigned to a central test station" (1987). West Virginia Agricultural and Forestry Experiment Station Bulletins. 693.

https://researchrepository.wvu.edu/wv_agricultural_and_forestry_experiment_station_bulletins/587 


\section{Factors Affecting Gain of Beef Bulls Consigned to a Central Test Station}

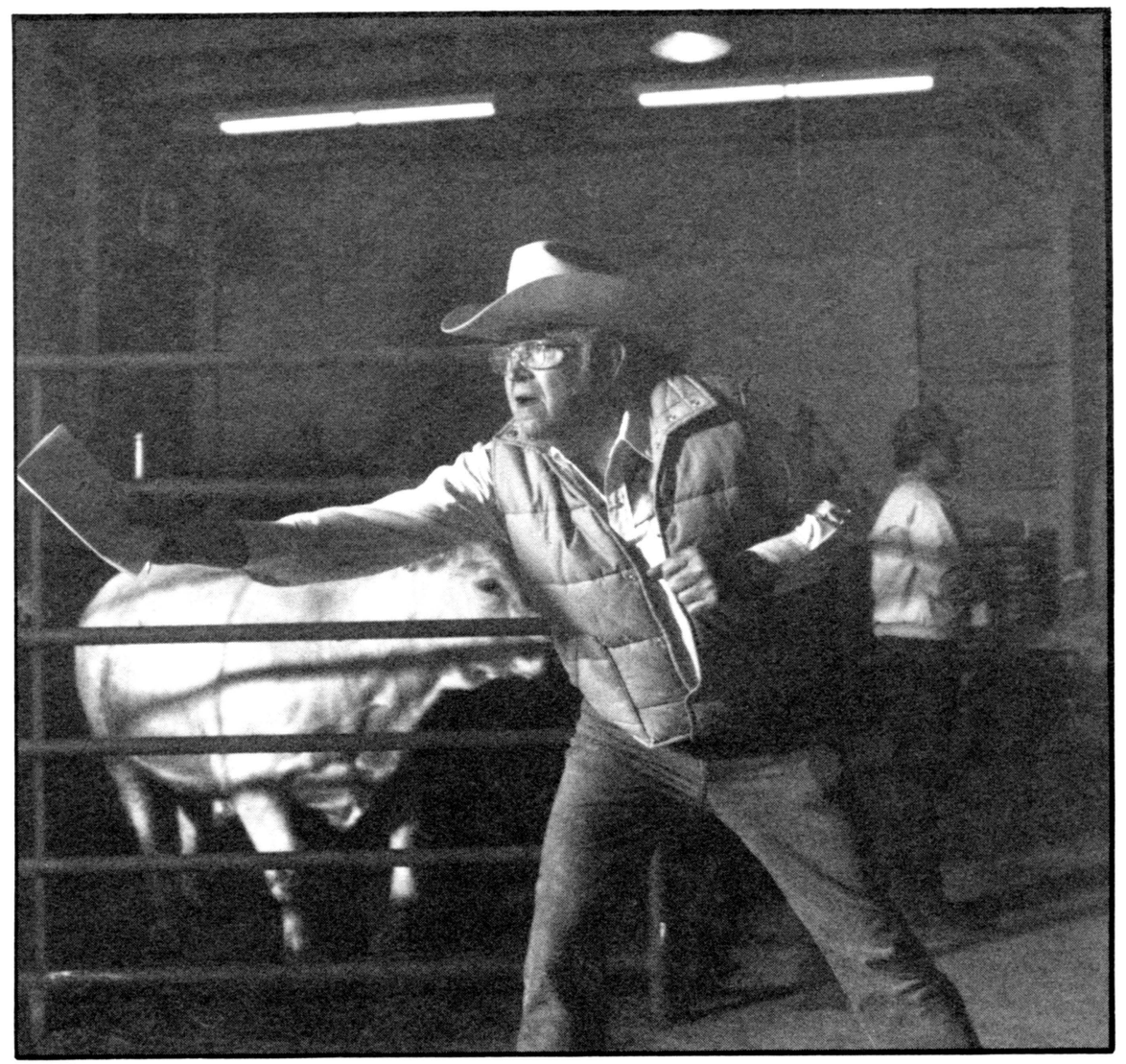

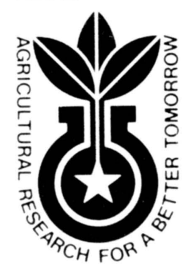

Hatch Act Centennial 1887-1987

\section{BULLETIN 693}

February 1987

Agricultural and Forestry Experiment Station West Virginia University 
[Blank Page in Original Bulletin] 


\section{Contents}

Introduction $\ldots \ldots \ldots \ldots \ldots \ldots \ldots \ldots \ldots \ldots \ldots \ldots \ldots \ldots \ldots \ldots$

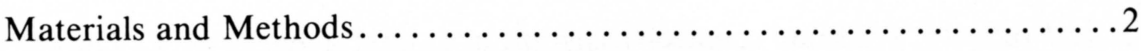

Eligibility for Test $\ldots \ldots \ldots \ldots \ldots \ldots \ldots \ldots \ldots \ldots \ldots \ldots \ldots \ldots \ldots \ldots \ldots \ldots \ldots \ldots$

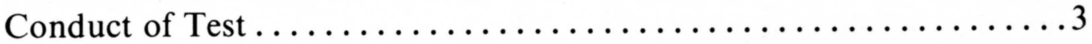

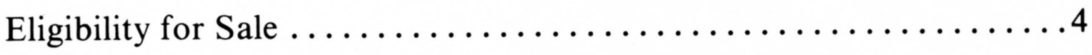

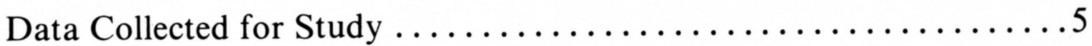

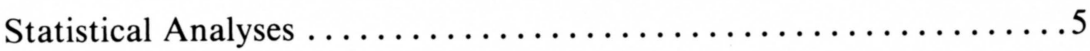

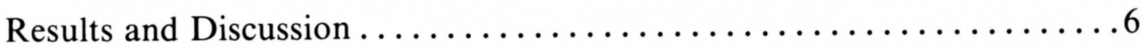

Correlations Among Gains and Weights on Test $\ldots \ldots \ldots \ldots \ldots \ldots$

Relative Importance of Each 28-Day Period...............

Analyses of Total Weight Gained and the Postweaning

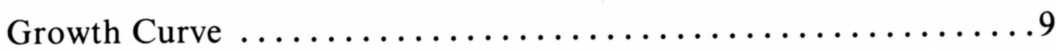

Probability of Being Sold $\ldots \ldots \ldots \ldots \ldots \ldots \ldots \ldots \ldots \ldots \ldots \ldots \ldots \ldots \ldots \ldots$

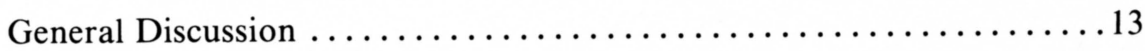

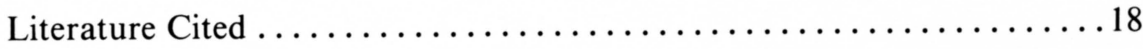




\section{AUTHORS}

C. L. Franklin, graduate research assistant in animal science; W. V. Thayne, statistician; W. R. Wagner, Extension specialist, (animal breeding and genetics); L. P. Stevens, associate animal scientist; E. K. Inskeep, scientist (reproductive physiology).

West Virginia University

Agricultural and Forestry Experiment Station

College of Agriculture and Forestry

Robert H. Maxwell, Director

Morgantown 


\title{
Factors Affecting Gain of Beef Bulls Consigned to a Central Test Station
}

\author{
C.L. Franklin, W. V. Thayne, W. R. Wagner, L. P. Stevens, \\ and E. K. Inskeep
}

\section{Introduction}

Performance evaluation of beef cattle was initiated by the USDA around 1930. The first central bull testing program was formed in Texas in 1940 (Maddox, 1967; Melton et al., 1973). West Virginia initiated performance testing for 205-day weight in beef herds in 1961. A program testing bulls for performance in the feedlot was begun in October, 1966. Interest in the test led to the establishment of a central bull testing station at Reymann Memorial Farms, a substation of the West Virginia Agricultural and Forestry Experiment Station, at Wardensville. The 140-day testing program, officially started in 1967-68, has continued annually during the period of October to March.

Increases in feed and labor costs have been coupled with relatively low prices for feeder calves since 1974. Limited sale prices of most tested bulls have meant that consignment to the central bull test and sale has not been a profitable marketing mechanism for the seedstock producer. In addition, some commercial cattle producers have felt that tested bulls were overconditioned at the completion of the test. These factors contributed to the decision to establish a test with a high roughage diet at Gap Mills in 1982. A question has been raised whether the central test at Wardensville could or should be shortened from the standard 140 days used since 1967 (and recommended by the Beef Improvement Federation).

The beef industry's objective has been to obtain the most accurate estimates possible of the breeding values, or differences in genetic merit, of animals. The effectiveness of selection is maximized when environment is controlled as much as possible so that observed differences among animals are due primarily to genetic factors. In 1947, Knapp and Clark concluded that environmental factors affected gain more than genetic factors in the first 84-day period of a 252-day postweaning test while genetic and environmental factors affected gain equally in the second period. By the third 84-day period gains were influenced to a great extent by heredity. In contrast, Swiger (1961), 
studying three times as many animals, reported that heritability was highest for the second 28-day interval of a 140-day test, but decreased during successive periods. Swiger felt that this was an indication that environmental differences became more important as the feeding period progressed.

Studying calves fed a high energy ration starting immediately after weaning, Swiger and Hazel (1961) found that weight after a 90-day feeding period was 95 percent as accurate as actual weight at one year of age in predicting the genotype for yearling weight. Thus, accurate selection for final weight could be achieved at an early age when bulls are on a high level of energy intake, such as used in the central test at Wardensville. In other studies, Hoff and Brinks (1977) and Buchanan and McPeake (1986) found correlations of .93 and .91 , respectively, between gain during the first 112 days and total 140 -day gain. This indicates that 83 to 86 percent of the variation in total gain could be attributed to gain during the first 112 days of the test.

Environmental correlations of weaning weight with postweaning gains indicated that good preweaning environment was a handicap to early postweaning gains but enhanced later gains. There may be some compensatory gains in the feedlot when animals are in a poor environment prior to weaning. However, there has been a low relationship observed between preweaning and postweaning performance (Koch and Clark, 1955; Patterson et al., 1949, 1955). In fact, Koch et al. (1973) reported that bulls which gained more before weaning due to environmental conditions had a competitive advantage for feed consumption in the feedlot over their genetically comparable testmates.

The present study was initiated to: (1) examine patterns of gain of bulls in the Wardensville test station, (2) determine the proportion of the variance in gain on test accounted for by each 28-day period of the 140-day test and (3) ascertain how much the performance rankings of bulls would change from one 28-day period to another. From these data, recommendations have been made for alternative approaches to reduce the costs of testing postweaning performance of bulls consigned to a central test station.

\section{Materials and Methods}

Data were collected from the bull test at WVU Reymann Memorial Farms in Wardensville, West Virginia, from 1975 through 1984. Two hundred thirtyone farms consigned 1,159 Angus bulls representing 325 sires, 348 Hereford bulls representing 116 sires, and 296 Simmental bulls representing 102 sires to be performance tested. Bulls of each breed were registered (or, in the case of Simmentals, recorded as $1 / 2$ blood or higher) by the respective breed association. 


\section{Eligibility for test}

To be eligible for entry, calves must have been born on or after November 15 of the previous year (December 1 in the 1976-77 test) and no later than March 31 of the year of the start of each test and raised on their natural dams. In the 1975 to 1982 tests, calves had to have a minimum 205-day weight, adjusted for age of dam, of 500 pounds if noncreep fed and 525 pounds if on creep. Bulls accepted for the 1983 and 1984 tests had to weigh a minimum of 2.2 pounds per day of age at delivery to the station. Structurally unsound or small-framed bulls were not accepted, and a clean pedigree for dwarfism was required. All animals had to have an official state health certificate and negative tests for tuberculosis and brucellosis prior to delivery to the test station. In addition, the bulls must have been vaccinated for: infectious bovine rhinotracheitis, parainfluenza 3, blackleg, malignant edema, Hemophilus somnus, and leptospirosis.

\section{Conduct of test}

The schedule of conduct of the test is presented in Figure 1. Bulls were delivered to the test station over a three-day period and were assigned to lots according to age and breed, within limitations of the facility. Upon delivery, the animals were dewormed, vaccinated for bovine viral diarrhea, and for some of the years, booster vaccinated for Hemophilus somnus and clostridial diseases. Pour-on insecticide was applied after delivery. Calves with active pinkeye, ringworm or warts were not admitted to the test. All horned bulls had to have been dehorned and the wound healed before delivery. Within a few days after arrival, bulls were started on the test ration for a pretest adjustment period. This period was 14 days in the $1975-76$ and 1978 to 1983 tests, 17 days in the 1976-77 test, and 21 days in the 1983-84 test. Thus, bulls were given some time to get started on full feed, and adjust to a new environment. Bulls were housed in a shed-type barn with open exercise lots.

Bulls were separated into two age groups and performance ratios were calculated within breed and age group. Bulls born between November 15 and January 31 (December 1 through January 31 in the 1976-77 test) were designated seniors while bulls born between February 1 and March 31 were considered juniors. Of the 1,159 Angus bulls consigned, 963 were juniors and 196 were seniors. There were 209 junior and 139 senior bulls in the Hereford breed. The Simmentals were made up of 205 juniors and 91 seniors.

Initial weight was determined as the average of two weights taken on a Monday and Wednesday with Tuesday representing the start of the 140-day test. Following the adjustment period, the bulls were fed, ad libitum, a ration which met the N.R.C. requirements for growing and finishing steers (.83 

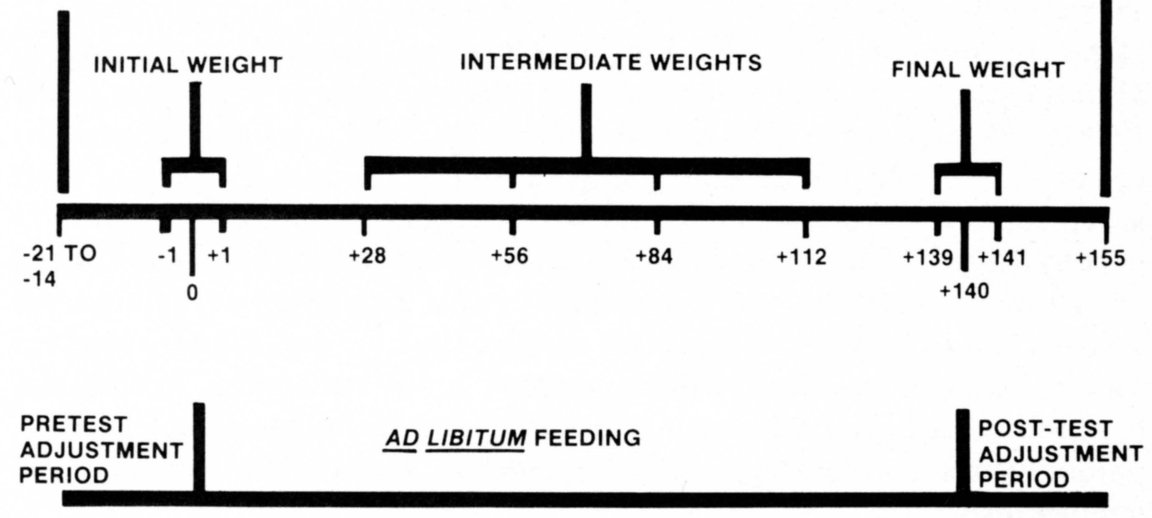

Figure 1. Schedule of conduct of the central bull test.

$\mathrm{Mcal} /$ pound $\mathrm{NE}_{\mathrm{m}}$ and $.57 \mathrm{Mcal} /$ pound $\mathrm{NE}_{\mathrm{g}}$ on a dry matter basis). Fresh water and a complete mineral mix were available at all times. In the 1983-84 test, $75 \mathrm{mg} / \mathrm{head} /$ day of monensin sodium was added to the ration, to reduce the incidence of bloat and to increase feed efficiency. Following the completion of the second period of the 1983-84 test, the ear corn in the ration was reduced by 2 percent because of low moisture content. It was replaced with shelled corn and grass hay. A minimum incidence of digestive disturbances was noted during the feeding period. Management practices, other than those specified, remained constant throughout the nine years of performance tests studied.

Bulls were weighed every 28 days during the test period except in the 1982-83 test. During this test, the bulls were not weighed at the end of the first 28-day period. At the conclusion of the performance test, final weight was determined by the average of two weights taken on a Monday and Wednesday. The bulls were then started on a post-test adjustment period during which the proportion of corn in the ration was decreased and the proportion of roughage was increased.

\section{Eligibility for sale}

Each year a sale was held following the conclusion of the post-test adjustment period. Approximately the top two-thirds of the bulls in each breed were sold, primarily on the basis of a growth index. Prior to the 1982-83 test, the index was determined by $1 / 2$ (average daily gain on test ratio + weight per day of age ratio). Since that time, the index has been calculated as $1 / 2$ (average daily gain 
on test ratio + 365-day weight ratio). Thus, the index used to select bulls for sale has taken into account both preweaning and postweaning performance.

The following were causes for ineligibility for sale: growth index in bottom one-third of breed group (or less than 95), herd weaning weight ratio less than 95 or unavailable, scrotal circumference less than $30 \mathrm{~cm}$, frame score (calculated from hip height) less than 3.5, reproductively unsound or infertile, structurally unsound, poor conformation, and undesirable disposition. For the tests in 1982 through 1984, bulls had to have a minimum ratio for average daily gain on test (ADG) of 92. In addition, bulls tested in 1983-84 had to have a 205-day weight of at least $500 \mathrm{lbs}$ and a herd 205-day weight ratio of at least 95, unless 205-day weights were over $600 \mathrm{lbs}$.

\section{Data collected for study}

Information recorded on each bull included: year in which the bull was tested, sire, farm which consigned the bull, breed, the calf's age classification, adjusted 205-day weight, initial age and weight, intermediate weights taken every 28 days, final weight, ADG ratio, 365-day weight ratio, and index. Data from 1975 to 1982 were combined for all analyses. For the 1982-83 and 1983-84 tests, data were studied separately because of the changes in weighing dates and ration formulation, respectively.

\section{Statistical analyses}

All analyses were done using the Statistical Analysis System available through the West Virginia Network for Educational Telecomputing. To summarize the data, the mean and standard error of each variable were calculated on an annual basis. The regression of the mean for total weight gained on year of test was estimated along with its 95 percent confidence interval. Phenotypic correlations were estimated among gains and weights. In addition, part-whole phenotypic correlations between intermediate gains and total weight gained during the test were estimated for the data from 1975 to 1982.

To construct a model for total gain, data from 1975 to 1982 were analyzed using the general linear models procedure. Non-significant interactions were deleted from the model. In the final model, the Type I sums of squares for gain in each of the first four 28-day periods were used to determine the relative importance of each of the five periods during the nine tests studied.

A second model, for weight rather than gain, was developed using the data from 1975 to 1982 . This was done to examine sources of variation in the postweaning growth curves. Time, its quadratic effects, and the interactions of breed, farm, sire, junior-senior age classification, and breed by age with time were fitted into the model; year, breed, farm, sire, age and bull were absorbed to facilitate analysis. 
In order to determine the probability of a bull qualifying for the performance-tested sale based upon his performance at a given time during the test, the bulls were ranked into six groups on the basis of their weight gain at the conclusion of each period. The probability of a bull qualifying to be sold at the end of the test, given his ranking after each 28-day period, was calculated separately for the 1975 to $1982,1982-83$ and 1983-84 data. For these analyses, a minimum gain index of 95 and an ADG ratio on test of 92 were required for a bull to be eligible for sale. The formulas for both of these qualifications included adjustments for breed and for age group.

\section{Results and Discussion}

The linear regression of mean total weight gained during a test on year of testing was described by the equation: $\mathrm{Y}=423+5.89 \mathrm{X}$, where $\mathrm{Y}$ is the estimated total weight gained and $X$ is the year, coded from 1 to 9 . Thus, there has been a trend of gradually increasing total gains for bulls in this central bull test, averaging nearly 5.9 pounds per year. From year 1 to year 9 , total gain on test increased by approximately 47 pounds.

\section{Correlations among gains and weights on test}

Correlations of gains made during each of the five 28-day periods with total weight gained on test and final weight are presented in Table 1 for the 1975 through 1982, 1982-83 and 1983-84 tests. All of the correlations of intermediate gains during the five periods with total weight gained were positive, highly significant, and fairly constant from one period to the next.

\section{Table 1}

Correlations of Weight Gains of Bulls during Five Consecutive 28-Day

Periods with Final Weight and Total Weight Gained on Test.

\begin{tabular}{cccccccc}
\hline \hline Gain During & \multicolumn{3}{c}{ Final Weight } & & \multicolumn{3}{c}{ Total Gain } \\
\cline { 2 - 4 } \cline { 7 - 8 } \cline { 6 - 8 } & $1975-$ & $1982-$ & $1983-$ & & $1975-$ & $1982-$ & $1983-$ \\
& 1982 & 1983 & 1984 & & 1982 & 1983 & 1984 \\
\hline 1 & .40 & & .21 & & .56 & & .58 \\
2 & .29 & & .29 & & .49 & & .51 \\
3 & .28 & .22 & $.06^{\mathrm{a}}$ & & .52 & .55 & .43 \\
4 & .21 & .24 & .20 & & .45 & .32 & .38 \\
5 & .25 & .38 & $.13^{\mathrm{a}}$ & .53 & .59 & .53 \\
Total & .56 & .57 & .37 & & & \\
\hline
\end{tabular}

${ }^{a}$ All values reported are significant $(\mathrm{P}<.01)$ except these two. 
Correlation coefficients ranged from .32 to .59 indicating a strong positive association between gain made during any one period and total weight gained. Relationships among gains made during the test and final weight were not as high (.06 to .40). The correlation between final weight and total weight gained ranged from .37 to $.57(\mathrm{P}<0.01)$.

The correlations of initial weight and weights at the conclusion of each 28-day period with final weight and total weight gained are shown in Table 2. Between any intermediate weight and final weight there was a highly significant, positive correlation (.89 to .99 ).

The correlations observed between initial or intermediate weights and total weight gained increased as the bulls approached final weight. The values for the data from 1975 through 1982 were positive, significant and ranged from 0.12 to 0.56 . Initial weight had a low association with total weight gained ( -0.05 to 0.16 for the three sets of data). Similarly, Petty and Cartwright (1966) reported a phenotypic correlation of 0.17 for initial weight and total gain. Thus, while initial weight and final weight were highly related, the initial weight of a bull had essentially no influence on how much weight he gained during the test.

\section{Table 2}

Correlations of Weights of Bulls at Various Times with Final Weight and Total Weight Gained on Test.

\begin{tabular}{|c|c|c|c|c|c|c|}
\hline \multirow{2}{*}{$\begin{array}{l}\text { Weight at } \\
\text { Day }\end{array}$} & \multicolumn{3}{|c|}{ Final Weight } & \multicolumn{3}{|c|}{ Total Gain } \\
\hline & $\begin{array}{l}1975- \\
1982\end{array}$ & $\begin{array}{l}1982- \\
1983\end{array}$ & $\begin{array}{l}1983- \\
1984\end{array}$ & $\begin{array}{l}1975- \\
1982\end{array}$ & $\begin{array}{l}1982- \\
1983 \\
\end{array}$ & $\begin{array}{l}1983- \\
1984\end{array}$ \\
\hline 0 (Initial) & .89 & .90 & .91 & .12 & .16 & $-.05^{a}$ \\
\hline 28 & .92 & & .94 & .23 & & $.06^{\mathrm{a}}$ \\
\hline 56 & .95 & .96 & .96 & .32 & .37 & .14 \\
\hline 84 & .97 & .97 & .98 & .41 & .46 & .22 \\
\hline 112 & .98 & .99 & .99 & .48 & .50 & .28 \\
\hline 140 (Final) & & & & .56 & .57 & .37 \\
\hline
\end{tabular}

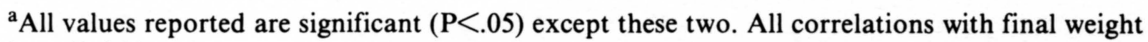
have $\mathrm{P}<.01$.

Using data from the 1975 to 1982 tests, part-whole correlations between performance in the first period, first plus second periods, etc. with total weight gained on test were obtained (Table 3). All of these correlations were positive, highly significant and in good agreement with values obtained by Hoff and Brinks (1977), and Buchanan and McPeake (1986), which are included in Table 3. The coefficient of determination $\left(R^{2}\right)$ can be used to estimate the amount of variation in total weight gained accounted for by the shorter 
periods. The correlation of 0.92 between gain through four periods and total 140-day gain indicated that 85 percent of the variation in total gain could be attributed to gain through 112 days. Part-whole correlations for all bulls by breed are shown in Figure 2. The correlation coefficients for gain during each period with total gain did not differ among breeds.

\section{Table 3}

Part-whole Correlations Among Postweaning Gains.

\begin{tabular}{lccc}
\hline \hline $\begin{array}{l}\text { Gain During } \\
\text { Period }^{\mathrm{a}}\end{array}$ & \multicolumn{3}{c}{ Correlation with Total Weight Gain } \\
\cline { 2 - 4 } & $\begin{array}{c}\text { Present } \\
\text { Study* }\end{array}$ & $\begin{array}{c}\text { Hoff and Brinks, } \\
1977\end{array}$ & $\begin{array}{c}\text { Buchanan and } \\
\text { McPeake, 1986 }\end{array}$ \\
\hline 1 & .56 & .51 & - \\
1 and 2 & .75 & .72 & - \\
1 through 3 & .85 & .85 & .82 \\
1 through 4 & .92 & .93 & .91 \\
\hline
\end{tabular}

${ }^{a}$ Each period was 28 days in length. Total gain was for five periods (140 days).

*All values are significant at $\mathrm{P}<.0001$.

\section{Relative importance of each 28-day period}

The percentages of the total variability in weight gained attributable to each 28-day period, using data from 1975 through 1984, are shown in Figure 3. Gain in period one accounted for slightly more than 30 percent of the variability, while gains during the second period contributed 23 and 22 percent, respectively, for the 1975 through 1982 and 1983-84 tests. Since the weight at the end of the first period was not recorded during the 1982-83 test, the data for variability in cumulative gain through the second period are presented. Together, the first two periods made up at least 50 percent of the variability in total gain during all of the tests studied. Gain in period three accounted for approximately 16 percent of the variability during the 1975 through 1982 tests. However, in the 1982-83 and 1983-84 tests this increased to over 20 percent. The period which contributed the least was the fourth ( 9 to 14 percent). Gain in period five accounted for 9 to 17 percent. Thus, if the test were to be shortened to 112 days, there would be a loss of approximately 15 percent of the information on total weight gained as compared to a 140-day test. This agrees with the conclusion from part-whole correlation $\left(R^{2}\right.$ for periods 1 through $4=.85$ ). 


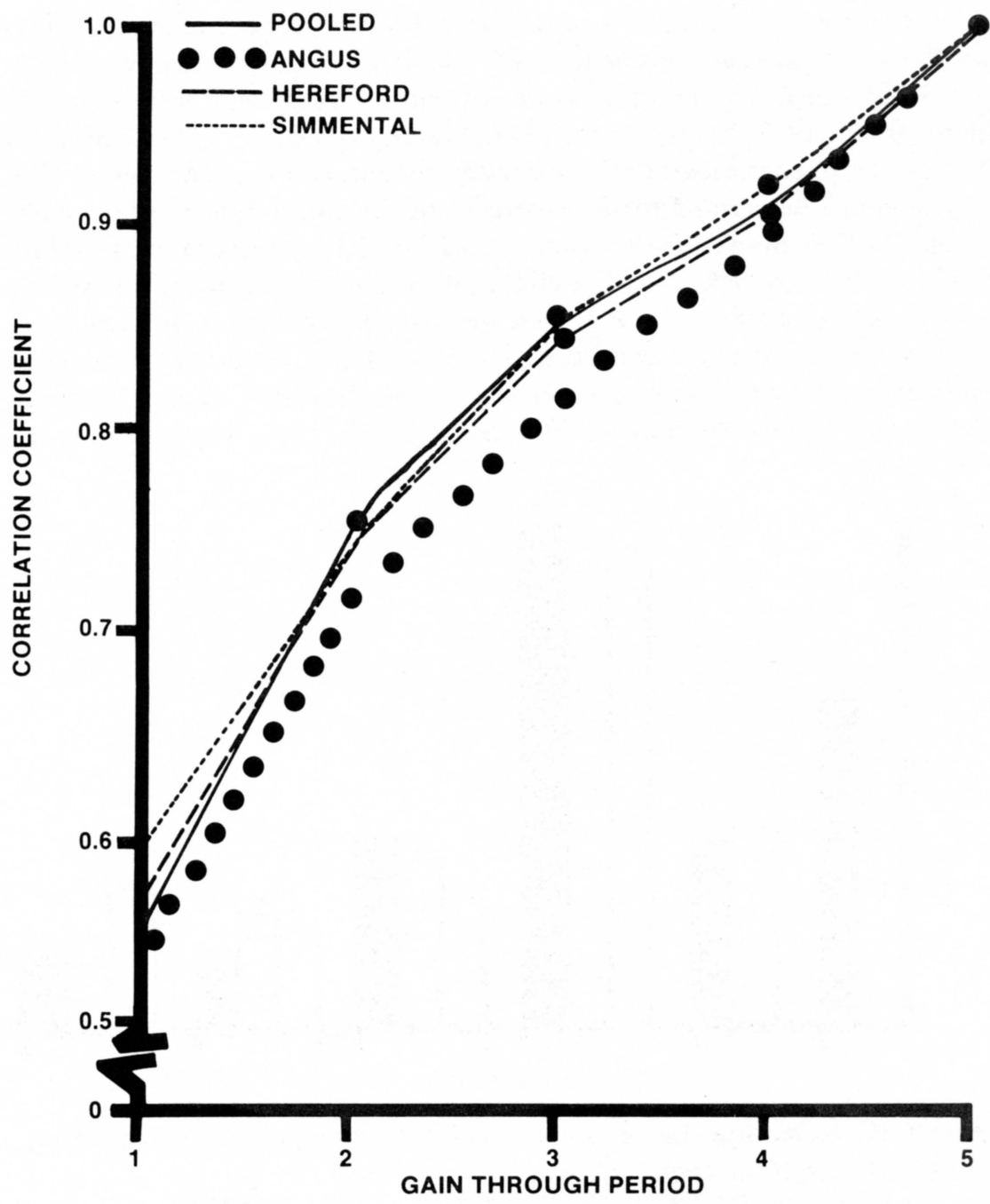

Figure 2. Part-whole phenotypic correlations with total weight gained, for Angus, Hereford and Simmental bulls, 1975-1982 tests.

\section{Analyses of total weight gained and the postweaning growth curve}

Initially, a model was developed for total weight gained which considered most of the independent variables, their interactions and quadratic effects in the data for 1975 through 1982. Sire and farm were not included because they represented part of the innate variability in this type of data and because 
neither of these variables had a significant effect on the postweaning growth curve (sire or farm $\times$ time interactions $\mathrm{P}>.10$ ). Numerous studies have already shown that sire is a significant source of variability in total weight gained (Shelby et al., 1960; Brown et al., 1974; Mavrogenis et al., 1978). Variables which contributed the least to the accuracy of the model were eliminated. The original model accounted for 88.8 percent of the variability in total weight gained. The final model (Table 4 ) accounted for 88.1 percent of the variability and did not display lack of fit. The effects of gains during each of the first four 28 -day periods on total weight gained were highly significant. In sum, these four periods accounted for 83 percent of the variability in this trait. Year had a significant effect on test gain, as numerous studies have shown for postweaning gain (McCormick et al., 1956; Shelby et al., 1960; Mavrogenis et al., 1978).

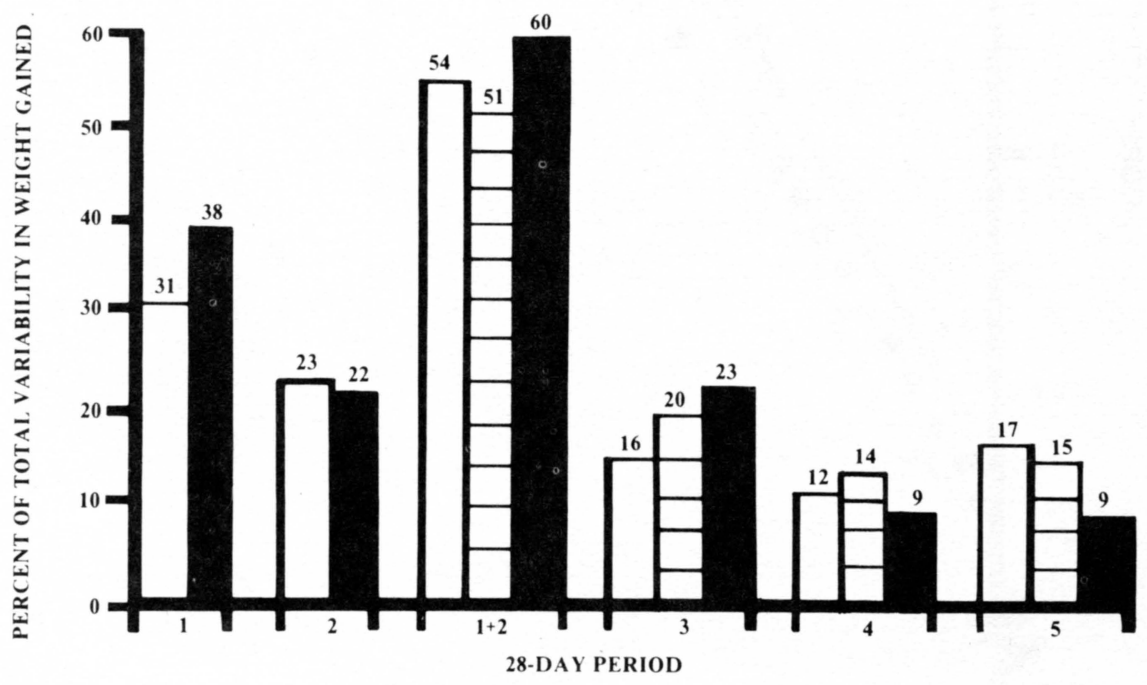

Figure 3. Relative importance of each 28-day feeding period in accounting for variability in total weight gained.

Data for 1975-1982

The mean total weight gains were lower for Angus and Herefords (430 lbs) than for Simmentals $(480 \mathrm{lbs})(\mathrm{P}<0.0001)$. However, breed by gain interactions were not significant for any of the 28 -day periods. Thus, if the test were to be shortened, no one breed would have an advantage over the others. The postweaning growth curves of the three breeds showed that Simmentals had the highest weights at all times during the test (Figure 4). Herefords and Angus did not differ in their weights throughout the test, even though the Angus averaged 12 days younger than the Herefords ( 232 vs. 246 days at the 


\section{Table 4}

Analysis of Variance for Total Weight Gained on Test: Final Model a, Data for 1975-1982.

\begin{tabular}{|c|c|c|c|}
\hline \multirow[b]{2}{*}{ Source of Variation } & \multirow[b]{2}{*}{ DF } & \multicolumn{2}{|c|}{ Type III } \\
\hline & & M.S. & F-Ratio \\
\hline Total & 1413 & & \\
\hline Year & 6 & 10847 & $32.30 * * *$ \\
\hline Age & 1 & 8610 & $25.64 * * *$ \\
\hline Breed & 2 & 7528 & $22.42 * * *$ \\
\hline \multirow[t]{3}{*}{ Breed $\times$ Year } & 12 & 603 & $1.79 *$ \\
\hline & & \multicolumn{2}{|c|}{ Type I } \\
\hline & & M.S. & F-Ratio \\
\hline Gain 1 & 1 & 1060678 & $3158.58 * * *$ \\
\hline Gain 2 & 1 & 799709 & $2381.44 * * *$ \\
\hline Gain 3 & 1 & 558773 & $1663.96 * * *$ \\
\hline Gain 4 & 1 & 416797 & $1241.17^{* * *}$ \\
\hline Lack of fit & 59 & 480 & 1.46 \\
\hline Error & 1329 & 329 & \\
\hline
\end{tabular}

a $\quad \mathrm{R}^{2}=0.88$

* $\quad \mathrm{P}<.05$

*** $\mathrm{P}<.001$

beginning of the test). Simmentals grew at a slightly faster rate during the test than did Herefords or Angus. Simmentals gained $3.43 \mathrm{lbs}$ per day, while Herefords and Angus gained $3.07 \mathrm{lbs}$ per day on test. There was a small, but significant effect of the interaction between breed and year on total weight gained.

On the average, bulls classified as juniors gained $436 \mathrm{lbs}$ on test, while seniors gained $442 \mathrm{lbs}(\mathrm{P}<0.01)$, with no breed by age interaction. Previous studies have shown that age differences could be ignored in postweaning tests if the range in initial age was no more than 60 to 90 days (Brinks et al., 1962; Swiger et al., 1963; Marlowe, 1965). However, there was a range in age of 136 days for bulls consigned to this central test. During the first 28-day period, seniors grew at a faster rate than juniors, 3.80 as compared to $3.45 \mathrm{lbs}$ per day $(\mathrm{P}<.01)$. Thereafter, juniors gained weight at a slightly faster rate than seniors, 3.03 versus 2.99 lbs per day $(\mathrm{P}<0.01)$. Senior bulls remained heavier than the juniors throughout the test (Figure 5). The average age of a junior bull at the end of the test was 364 days, while seniors averaged 413 days. 
Postweaning growth curves (Figures 4 and 5), derived from the model for insight, displayed a very strong linear tendency, with time on test $(\mathrm{P}<.01)$ accounting for most of the variability. This is in agreement with Koch et al. (1982). While there was a significant quadratic effect, it accounted for only a very small portion of the variability in weight. Age interacted significantly with the quadratic effect of time, but breed did not. Thus, there appeared to be a difference in the maturing patterns of the junior and senior bulls. However, there was not a difference among the breeds in regard to the maturity reached during the test, i.e., there was no evidence for a plateau in growth for any specific breed compared to the others.

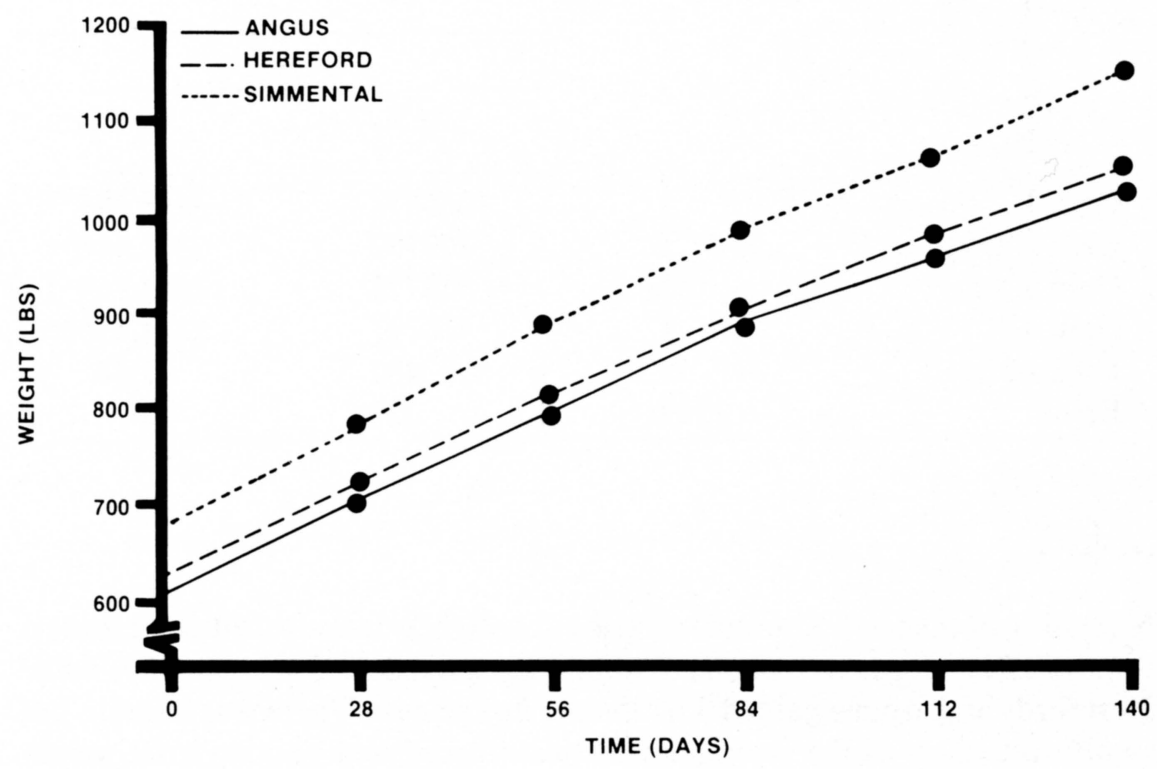

Figure 4. Postweaning growth curves of Angus, Hereford, and Simmental bulls, 1975-1982 tests.

\section{Probability of being sold}

In general, the probability of sale based on index for those bulls ranked in the lower $1 / 3$ at a given weigh period tended to decrease as the test progressed, while the upper $2 / 3 \mathrm{had}$ an increased probability of being sold with time on test (Figures 6 and 7). In the data for 1975 through 1982, there was a 31 percentage point difference in probability of being sold between the bulls in the fourth $1 / 6$ and the fifth $1 / 6$ at 112 days (Figure 6). By this time, the lowest 


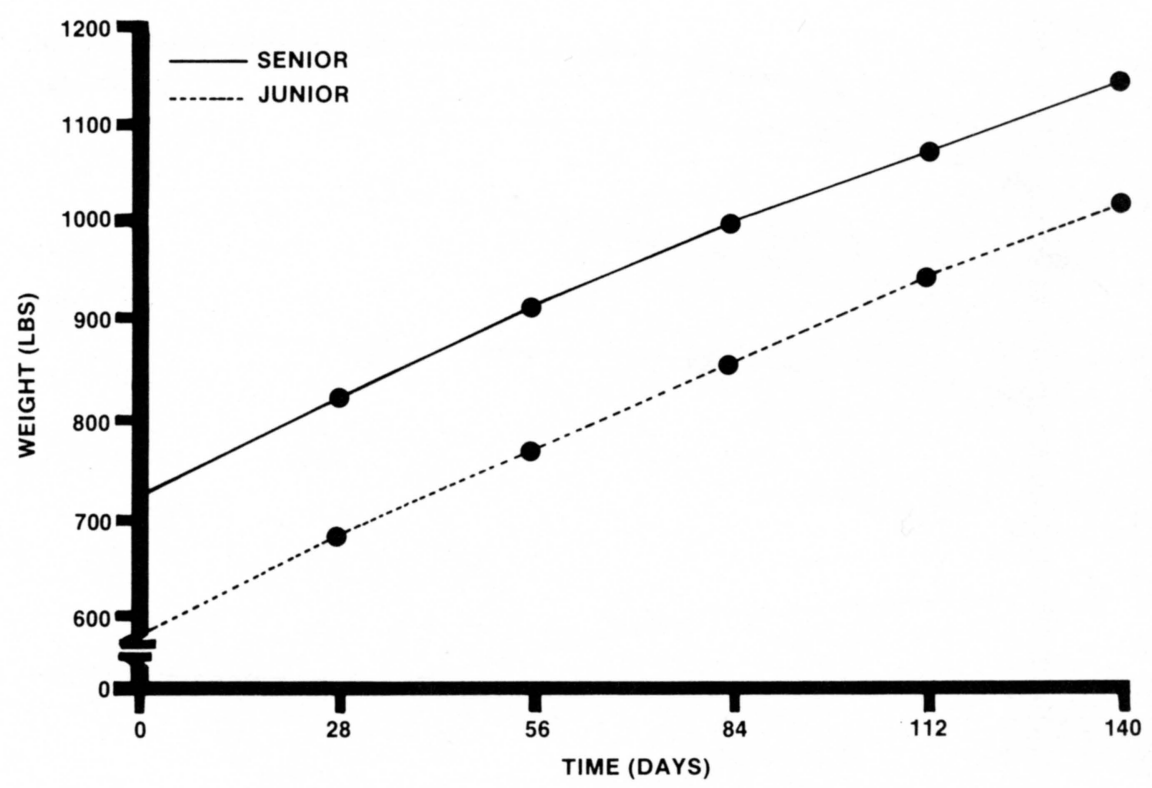

Figure 5. Postweaning growth curves of junior and senior bulls, 1975-1982 tests.

$1 / 6$ of the bulls had only a 12 percent chance of making the sale while 45 percent of the next lowest $1 / 6$ qualified to be sold. Those bulls ranked in the upper $1 / 2$ had over an 80 percent chance of qualifying for sale after only 56 days on test. Results from the 1982-83 test followed similar patterns. However, data for 1983-84 did not display the wide difference between the upper $2 / 3$ and the fifth $1 / 6$ of the bulls at 112 days in terms of their probability of being sold (Figure 7).

\section{General Discussion}

Most postweaning growth studies have used animals from experiment station herds or field records from selected herds. There has been less work done with bulls consigned to a central test station. This study has attempted to examine the factors which affect the weight gain of bulls consigned to a 140-day performance test. The variability in background of the bulls included in the data is apparent, in that 543 sires were represented and 231 farms consigned bulls over the nine years of tests studied. Apparently, progress has been made in providing for sale performance-tested bulls which can transmit the ability 


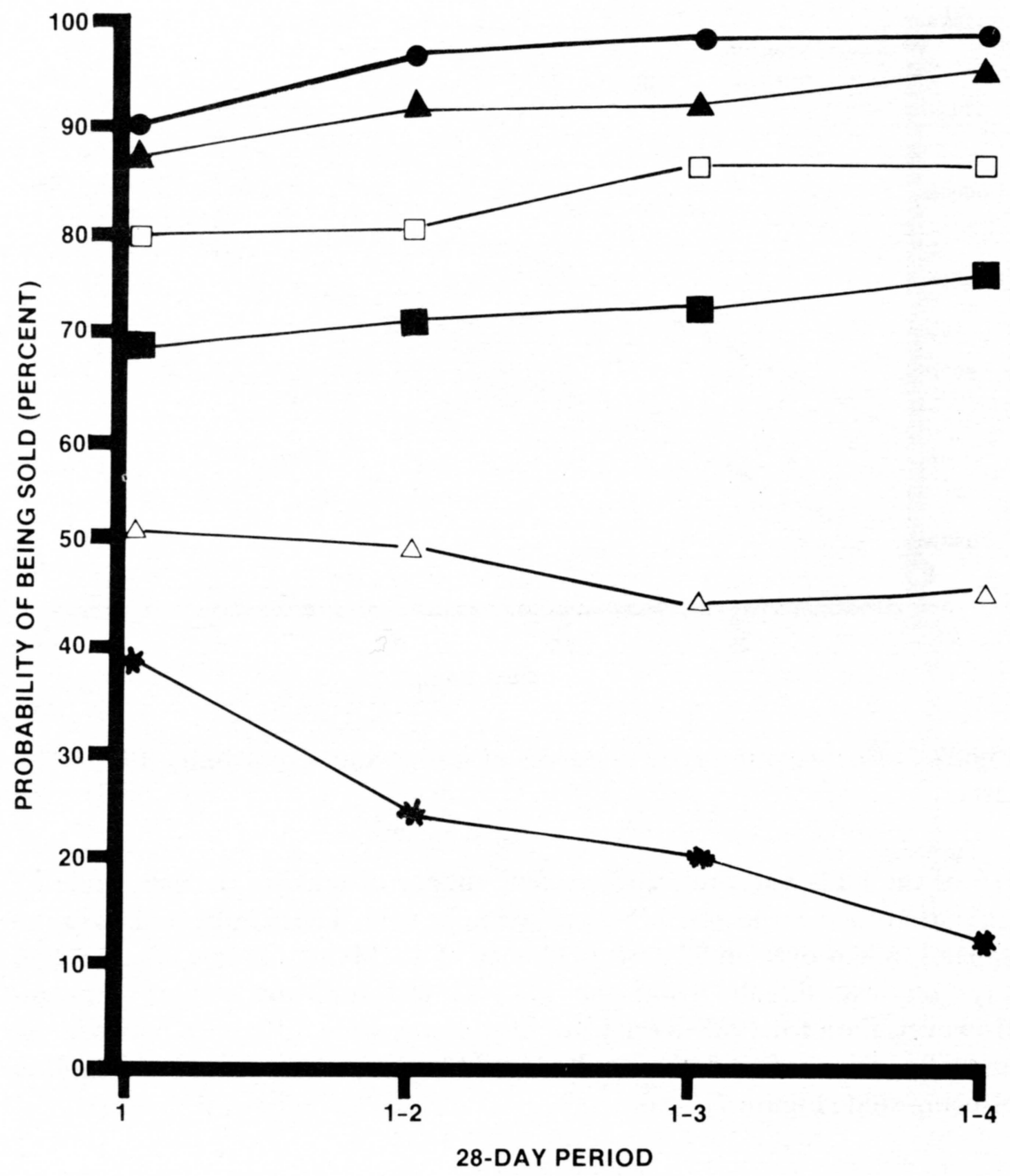

Figure 6. Probability of qualifying for sale in relation to rank order at intermediate points during the test, 1975-82. Ranks are as follows: -top $1 / 6 ; \boldsymbol{\Delta}$-second $1 / 6 ; \square$-third $1 / 6 ; \square$-fourth $1 / 6 ; \Delta$-fifth $1 / 6$; and -bottom $1 / 6$.

to gain weight rapidly. Total weight gained on test has continued to increase over the years examined (1975 through 1984).

Weight that a bull gains during a 140-day postweaning test obviously will reflect gains made during each of the five 28 -day periods. This study has confirmed that fact; however, the proportion of the variability in total gain 


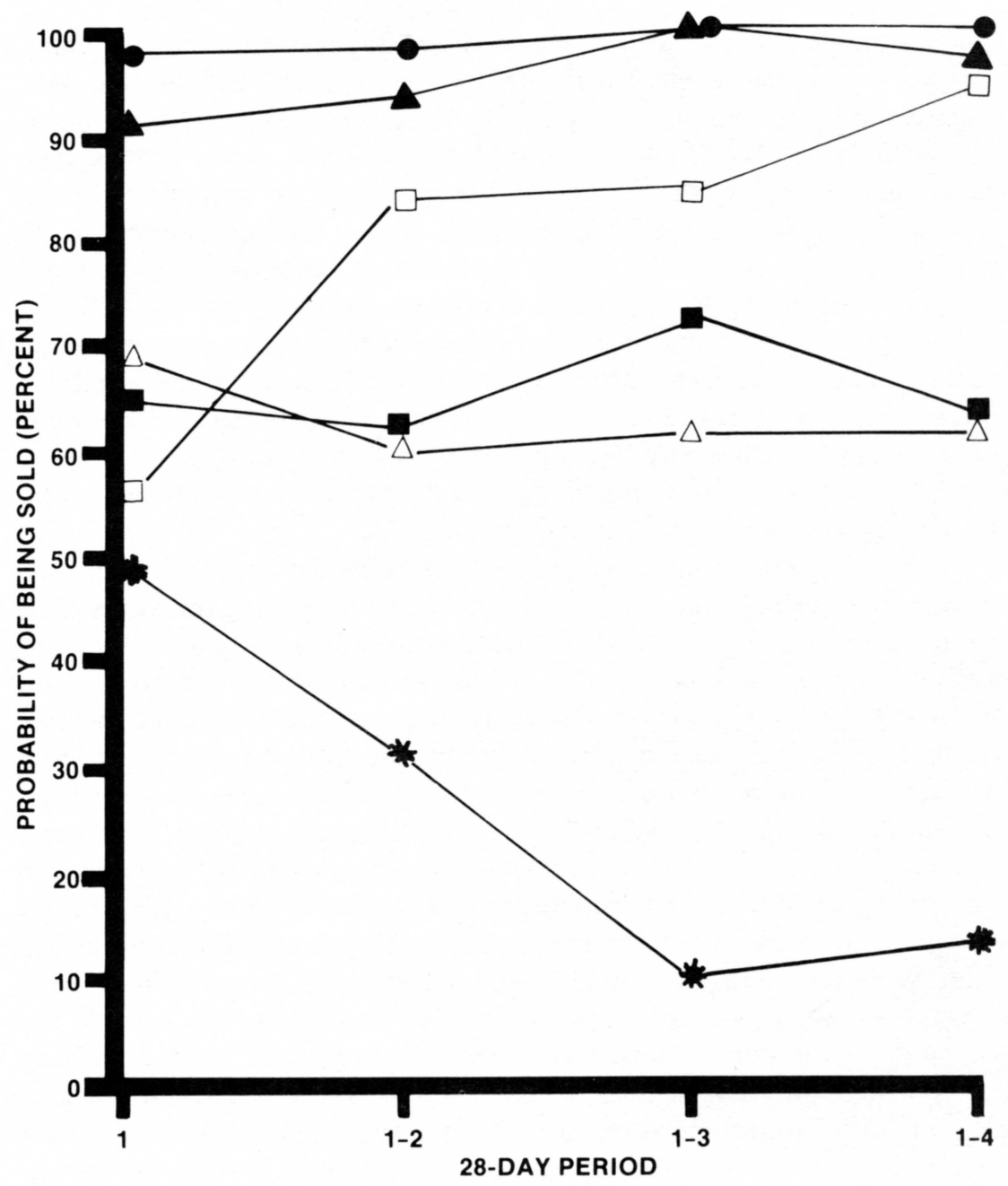

Figure 7. Probability of qualifying for sale in relation to rank order at intermediate points during the test, 1984. Ranks are as follows: -top 1/6; $\Delta$-second $1 / 6 ; \square$-third $1 / 6 ; \square$-fourth $1 / 6 ; \Delta$-fifth $1 / 6$; and * bottom $1 / 6$.

accounted for by each period was different. The amount gained by the end of the second 28-day period of the test had a great effect on the total weight gained (approximately 50 percent of the variability). The remaining variability in total gain was divided equally, for the most part, among the last three periods. 
In assessing whether or not the standard 140-day test could be shortened, the results of this study agree with the previous reports that the first four periods accounted for 83 to 85 percent of the variability in total weight gained (Hoff and Brinks, 1977; Buchanan and McPeake, 1986). Other studies have shown that gain during the fifth period is influenced to a great extent by non-genetic factors and that weight after a 90-day feeding period was 95 percent as accurate as yearling weight in predicting genotype for weight at a year of age (Swiger and Hazel, 1961). Therefore, a 112-day test is feasible. It would help to decrease costs, hasten progress in selecting superior individuals by making records available earlier, and perhaps reduce any negative effects of excessive fattening. Ration costs might be reduced by more than 20 percent since efficiency of gain would be declining in the final 28-day period, when a greater proportion of the tissue being laid down would be expected to be adipose tissue (Lofgreen and Garrett, 1968).

West Virginia began a second central bull test in 1981 with a ration higher in roughage and lower in energy content than the diet fed during this study. The different ration was used in an effort to decrease feed costs and eliminate excessive fattening or body condition seen in some bulls completing the Wardensville test. While the results of this study indicate that a 112-day test could be implemented at Wardensville with little loss of information, this procedure could not be recommended for the high roughage test until similar data from that test are examined. When energy intake is reduced, the testing period may have to be longer in order to accurately evaluate performance for growth (Swiger et al., 1963). Estimates for heritability of gains made on high roughage rations are lower than for gains achieved on high concentrate feeding (Warwick, 1958; Clark et al., 1963). Recent work has confirmed these findings. Realized heritabilities of only .07 for final liveweight and .09 for postweaning gain were reported for Hereford bulls and their crossbred progeny tested on pasture (Baker et al., 1984). In contrast, Wilton and McWhir (1985) found correlations of sire and progeny performance in central test stations of .20 for weaning and yearling weights and .16 for postweaning gain. In that study, which also used Hereford bulls, heritability of gain on test was .50 .

In addition to shortening the entire test, it appears that the lowest gaining $1 / 6$ of the bulls could be withdrawn after 84 days on test. These bulls had at most a 20 percent chance of being eligible for sale on the basis of index. With an average of 200 bulls in the test each year, the practice of culling the low $1 / 6$ at 84 days would remove only 7 bulls that would have been sold (mostly at prices below costs). Removal of these bulls would raise mean ADG and thus lower the ADG ratios for all bulls completing the test, but would have minimal effects on the ranking of these ratios.

Initial weight on test did not have a significant effect on gain. In addition, 
there was a low phenotypic correlation between initial weight and total weight gained. The fact that the weight at which a bull comes into the test has no significant bearing on his ability to gain becomes an important consideration when examining the basis upon which a bull is sold. The index used during these tests has given equal weight to the ADG ratio and the weight per day of age or 365-day weight ratio. The latter two ratios place variable importance on the pretest performance of a bull. Especially in the case of senior bulls, who entered the tests at an average of 273 days of age, the emphasis placed on pretest weight in the index may be too great, depending upon the buyer's selection criteria. If the bull's progeny are to display the most rapid growth during the postweaning period, high initial weight should not be used as a selection criterion and the present index may be limiting progress. However, the bull's adjusted 205-day weight is a valuable indication of his maternal environment. Preweaning gain and weaning weight are of lower heritability than feedlot gain (Woldehawariat et al., 1977) but reflect the dam's milk production and mothering ability. If there were a strong desire to increase milking ability then the emphasis on pretest weight would be valid, so long as birth date, birth weight and creep feeding had been recorded correctly. Emphasis on weight might be particularly appropriate for individual purchasers who planned to save replacement heifers. However, since the 205-day ratios for each bull are provided in the sale catalog, the use of an index and the inclusion of preweaning gain (as a component of 365-day weight) in that index remain debatable procedures. 


\section{Literature Cited}

Baker, R.L., B.W. Wickham and C.A. Morris. 1984. "Relationship between central performance test for growth in Hereford bull and growth and carcass traits of progeny," Animal Prod. 39:371.

Brinks, J.S., R.T. Clark, N.M. Kieffer, and J.R. Quesenberry. 1962. "Genetic and environmental factors affecting performance traits of Hereford bulls," $J$. Animal Sci. 21:777.

Brown, C.J., J.E. Brown, and W.T. Butts. 1974. "Evaluating relationships among immature measures of size, shape, and performance of beef bulls. IV. Regression models for predicting postweaning performance of young Hereford and Angus bulls using preweaning measures of size and shape," $J$. Animal Sci. 38:12.

Buchanan, D.S. and C.A. McPeake. 1986. "A comparison of 140 day vs shorter test periods for evaluating average daily gain in beef bulls at central test stations." 1986 Anim. Sci. Res. Report. Oklahoma Agr. Expt. Sta. p. 14; J. Animal Sci. 63 (Suppl. 1): 209.

Clark, R.T., J.S. Brinks, R. Bogart, L.A. Holland, C.B. Roubicek, O.F. Pahnich, J.A. Bennet, and R.E. Christian. 1963. Beef cattle breeding research in the Western region. Oregon Agr. Exp. Sta. Res. Bul. 73.

Hoff, C.G. and J.S. Brinks. 1977. "Repeatability of 28-day measures of performance traits on test." 28th Annual Beef Cattle Improvement Report and Sale Data. Colorado State University Exp. Sta. pp. 15-16.

Knapp, B. Jr. and R.T. Clark. 1947. "Genetic and environmental correlations between growth rates of beef cattle at different ages," J. Animal Sci. 6:174.

Koch, R.M. and R.T. Clark. 1955. "Influence of sex, season of birth, and age of dam on economic traits in range beef cattle," J. Animal Sci. 14:386.

Koch, R.M., L.V. Cundiff, K.E. Gregory, and G.E. Dickerson. 1973. “Genetic and phenotypic relations associated with preweaning and postweaning growth of Hereford bulls and heifers," J. Animal Sci. 36:235.

Koch, R.M., L.V. Cundiff, and K.E. Gregory. 1982. "Influence of postweaning gain interval on estimates of heritability and genetic correlations," $J$. Animal Sci. 55:1310.

Lofgreen, G.P. and W.N. Garrett. 1968. "A system for expressing net energy requirements and feed values for growing and finishing beef cattle," J. Animal Sci. 27:793-806.

Maddox, L.A. 1967. "State extension services' stake in the record of performance program," J. Animal Sci. 26:1267. 
Marlowe, T.J. and D.W. Vogt. 1965. "Heritabilities, phenotypic correlations and genetic correlations involving preweaning gain and weaning grade of beef calves," J. Animal Sci. 24:502.

Mavrogenis, A.P., E.U. Dillard, and O.W. Robison. 1978. "Genetic analysis of postweaning performance of Hereford bulls," J. Animal Sci. 47:1004.

McCormick, W.C., B.L. Southwell, and E.J. Warwick. 1956. Factors affecting performance in herds of purebred and grade Polled Hereford cattle. Ga. Exp. Sta. Bul. NS5.

Melton, A.A., L.A. Maddox, Jr., W.E. Kruse, and R.E. Patterson. 1973. The evolution of performance testing of beef cattle in Texas. Texas A\&M University, College Station (Mimeo.).

Patterson, R.E., J.H. Jones, J.J. Bayles, and R.V. Turnbough. 1949. "Performance testing and progeny testing of beef breeding stock as an aid to selection," J. Animal Sci. 8:608.

Patterson, R.E., T.C. Cartwright, J.H. Jones, and J.J. Bayles. 1955. "Performance testing of beef breeding stock," J. Animal Sci. 14:1034.

Petty, R.R. Jr. and T.C. Cartwright. 1966. A summary of genetic and environmental statistics for growth and conformation traits of young beef cattle. Texas A\&M, Texas Agr. Exp. Sta., Departmental Technical Report No. 5.

Shelby, C.E., R.T. Clark, J.R. Quesenberry, and R.R. Woodward. 1960. "Heritability of some economic characteristics in record of performance bulls," J. Animal Sci. 19:450.

Swiger, L.A. 1961. "Genetic and environmental influences on gain of beef cattle during various periods of life," J. Animal Sci. 20:183.

Swiger, L.A. and L.N. Hazel. 1961. "Optimum length of feeding period in selecting for gain of beef cattle," J. Animal Sci. 20:189.

Swiger, L.A., K.E. Gregory, R.M. Koch, W.W. Rowden, V.H. Arthaud, and J.E. Ingalls. 1963. "Evaluating postweaning gain of beef calves," J. Animal Sci. 22:514.

Warwick, E.J. 1958. "Fifty years of progress in breeding beef cattle," $J$. Animal Sci. 17:922.

Wilton, J.W. and J. McWhir. 1985. "Individual and progeny measurements of growth in station and herd tests," J. Animal Sci. 61:107.

Woldehawariat, G., M.A. Talamantes, R.R. Petty, Jr., and T.C. Cartwright. 1977. A summary of genetic and environmental statistics for growth and conformation characters of young beef cattle. Texas Agr. Exp. Sta. Tech. Rep. No. 103. 


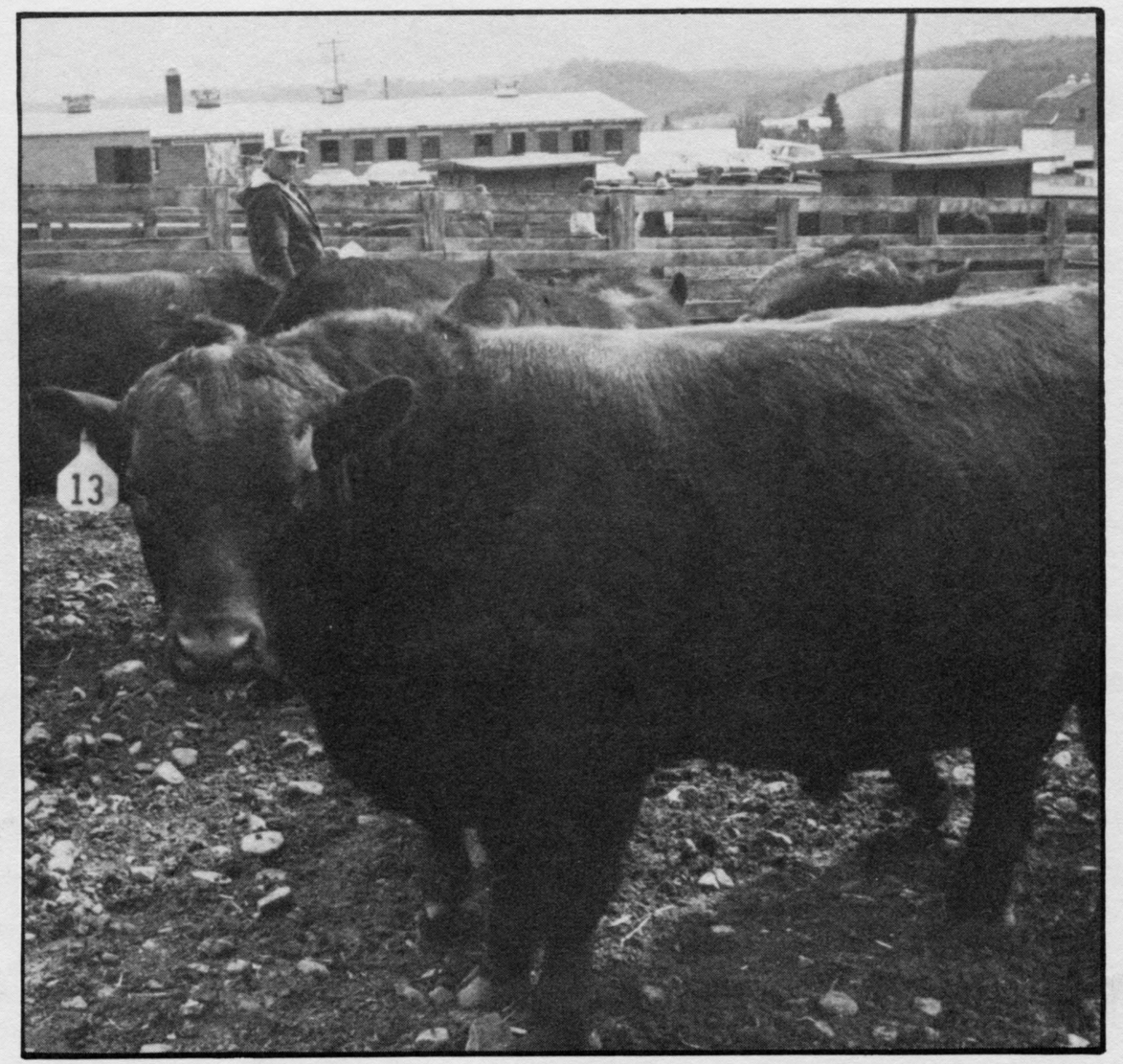

